\title{
A Passive EMI Filter with Access to the Ungrounded Motor Neutral Line
}

\section{—Its Effect on Attenuating Bearing Current-}

\author{
Shunsuke Tamura Student Member (Tokyo Institute of Technology) \\ Hirofumi Akagi Member (Tokyo Institute of Technology)
}

Keywords: bearing current, common-mode voltage, motor neutral line, passive EMI filters

Recently, attention has been paid to bearing failure in an inverterdriven motor. It is well-known that most of the bearing failure may be caused by bearing currents flowing inside the motor. A three-phase voltage-source PWM inverter using IGBTs produces a common-mode voltage including high-frequency components, which is considered as a zero-sequence voltage. The common-mode voltage induces a shaft voltage between the motor shaft and the motor frame. When the shaft voltage exceeds a threshold voltage ranging from 10 to $15 \mathrm{~V}$, breakdown of the grease film occurs in the motor bearing. At the instant, a short circuit is formed between the rotor and the frame, so that the shaft voltage suddenly goes down to zero. As a result, the bearing current with a peak value of about 1 A flows through the motor bearing in a $400-\mathrm{V} 3.7-\mathrm{kW}$ induction motor. This may cause damages such as fluting and pitting on the motor bearing, finally leading to bearing failure.

This paper focuses on a passive EMI filter that is unique in access to the motor neutral line. This filter consists of a common-mode filter and a $d v / d t$ reduction circuit. The common-mode filter can eliminate the $8-\mathrm{kHz}$ (switching frequency) component generated by a three-level neutral-point-clamped (NPC) PWM inverter from the motor terminals. Thereby, the shaft voltage can be reduced so that no breakdown of the grease film occurs. This means that no bearing current flows inside the motor. On the other hand, the $150-\mathrm{Hz}$ component generated by the diode rectifier still appears at the motor terminals because the common-mode filter has no capability of attenuating such a low-frequency component. However, since it is a low-frequency component with a small amplitude, it produces little effect on the bearing and leakage currents. The $d v / d t$ reduction circuit can make a value of $d v / d t$ as small as one-tenth, thus producing good effects on conducted EMI and stator-winding insulation.

An experimental system consists of a 400-V three-level NPC PWM inverter with a switching frequency of $8 \mathrm{kHz}$, a $400-\mathrm{V}, 3.7-$ $\mathrm{kW}$, 4-pole three-phase induction motor, and the passive EMI filter designed and fabricated in this paper.

Fig. 1 shows the experimental waveforms when no EMI filter is connected. The waveform of the shaft voltage suddenly went down to zero at the moment it exceeded about $10 \mathrm{~V}$. The bearing current with a peak value of about $1 \mathrm{~A}$ was observed in this experimental system. The bearing current $i_{B}$ has no relationship to the ground leakage current $i_{G}$ because the bearing current circulates inside the motor. The peak value of the leakage current reaches $500 \mathrm{~mA}$ in Fig. 1(a). This current may cause conducted and/or radiated EMI.

Fig. 2 shows the experimental waveforms when both $d v / d t$ reduction circuit and the common-mode filter are connected between the inverter and the motor. The waveform of the shaft voltage is reduced to a peak value of about $1 \mathrm{~V}$ as a result of having eliminated the common-mode voltage from the motor terminals. Therefore, no breakdown occurs in the bearing because the shaft voltage is lower than the breakdown voltage. As a result, it is concluded that the passive EMI filter can suppress the bearing current as well as ground leakage current, as shown in Fig. 2(b).

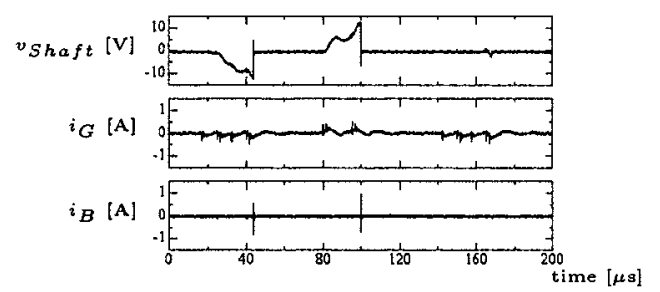

(a) Switching frequency-based time scale

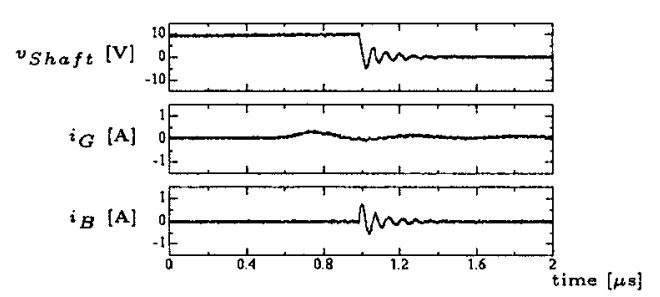

(b) Time-expanded waveforms of (a)

Fig. 1. Experimental waveforms when no filter is connected

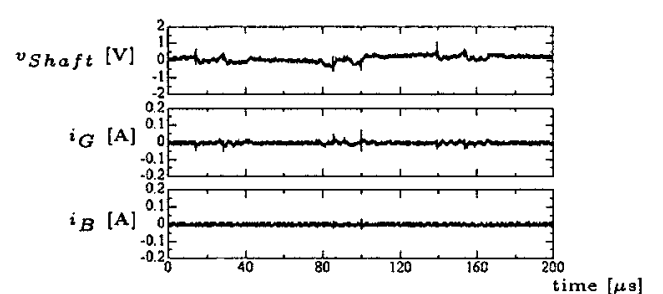

(a) Switching frequency-based time scale

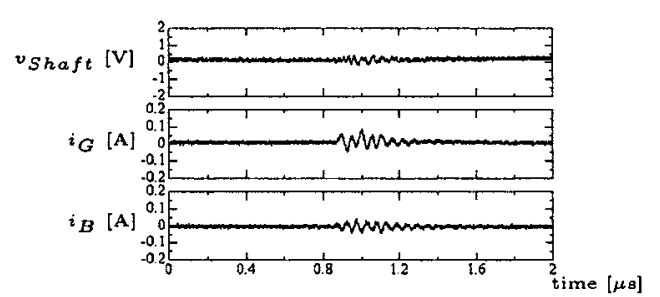

(b) Time-expanded waveforms of (a)

Fig. 2. Experimental waveforms when both the $d v / d t$ reduction circuit and the common-mode filter are connected 


\title{
モータ中性線を利用したパッシブEMI フィルタ —ベアリング電流の抑制効果
}

\author{
学生員 田村 俊輔* 正 員 赤木 泰文*
}

\author{
A Passive EMI Filter with Access to the Ungrounded Motor Neutral Line \\ - Its Effect on Attenuating Bearing Current-_
}

Shunsuke Tamura*, Student Member, Hirofumi Akagi*, Member

\begin{abstract}
This paper describes an effect of a passive EMI filter on preventing bearing current from flowing inside an inverterdriven motor. Motor-bearing damages are often caused by bearing currents resulting from breakdown of grease films in the motor bearing. The high-frequency common-mode voltage generated by the PWM inverter induces a shaft voltage between the rotor and the frame. When the shaft voltage exceeds a breakdown voltage of the grease films, a destructive instantaneous discharge current with a peak value of about $1 \mathrm{~A}$ flows through the motor bearing. The passive EMI filter, that is unique in access to the motor neutral line, can reduce the shaft voltage as a result of eliminating the highfrequency common-mode voltage from the motor terminals. Hence, no breakdown occurs in the grease film, so that no bearing current flows. The viability and effectiveness of the passive EMI filter is verified by experimental results obtained from a $400-\mathrm{V}, 3.7-\mathrm{kW}$ laboratory system.
\end{abstract}

キーワード : パッシブ EMI フィルタ, コモンモード電圧, モータ中性線, ベアリング電流, 浮遊容量

Keywords: passive EMI filter, common-mode voltage, motor neutral line, bearing current, parasitic capacitance

\section{1. まえがき}

誘導電動機の故障原因の多くは軸受損傷である。従来の 商用電源（正弦波電圧源）に接続した誘導電動機の軸受損 傷は機械的，熱的によるものであったが，近年はPWM イ ンバータによる誘導電動機の軸受電食が深刻な問題になっ てきている。PWM インバータが発生するコモンモード電 圧がモータ軸とフレーム間に軸電圧を誘発し，軸電圧が油 膜の絶縁破壊電圧に達するとベアリング電流が流れる。こ れが軸受電食の原因である(1)(2)。軸受電食は主としてべア リング電流密度で決まり, ベアリング電流密度と寿命に関 する論文が発表されている (3)。モータの回転数が低い場合 ではベアリング表面の粗さが原因でレースとボールが接触 し，絶縁破壊電圧以下でもベアリング電流（変位電流）が 発生する (4)。しかし，レースとボールの接触に起因するべ アリング電流は油膜の絶縁破壊に起因するベアリング電流 （放電電流）よりも小さく, 軸受電食を引き起こす恐れは少 ない。

\footnotetext{
* 東京工業大学 大学院理工学研究科 電気電子工学専攻

T 152-8552 東京都目黒区大岡山 2-12-1

Department of Electrical and Electronics Engineering,

Tokyo Institute of Technology

2-12-1, O-okayama, Meguro-ku, Tokyo 152-8552
}

油膜の絶縁破壞に起因するベアリング電流の抑制対策と して，従来から以下の方法が提案されている。

（1）固定子と回転子の間に静電シールドを挿入した誘 導電動機の採用 ${ }^{(3)}$ 。

(2) 接地ブラシの設置 ${ }^{(4)}$ 。

（3）絶縁ベアリング（例：セラミックベアリング）の 採用 ${ }^{(5)}$ 。

しかし，これらの対策は汎用性やコストに問題がある。

筆者らは先にモータ中性線を利用したパッシブ EMI フィ ル夕を提案し，コモンモード電圧を抑制することで漏れ電 流を抑制できること, 軸受油膜の絶縁を確保できることなど を検証した ${ }^{(6)}$ 。本論文では，このパッシブ EMI フィルタが ベアリング電流（放電電流）を完全に抑制できることを，べ アリング電流の測定可能な特殊構造の誘導電動機 $(400 \mathrm{~V}$, $3.7 \mathrm{~kW})$ を用いて実証する。この対策はモータ中性線を必 要とし, $\Delta$ 結線の誘導電動機には適用できないが, インバー 夕出力に受動素子を接続するだけでよく, 実用的な対策と 考えられる。

さらに本論文では，コモンモードに対するモータ内部の 等価回路を検討する。この等価回路は, パッシブ EMI フィ ルタの設計やベアリング電流の発生原因と電流経路を考察 する際に役立つものである。 


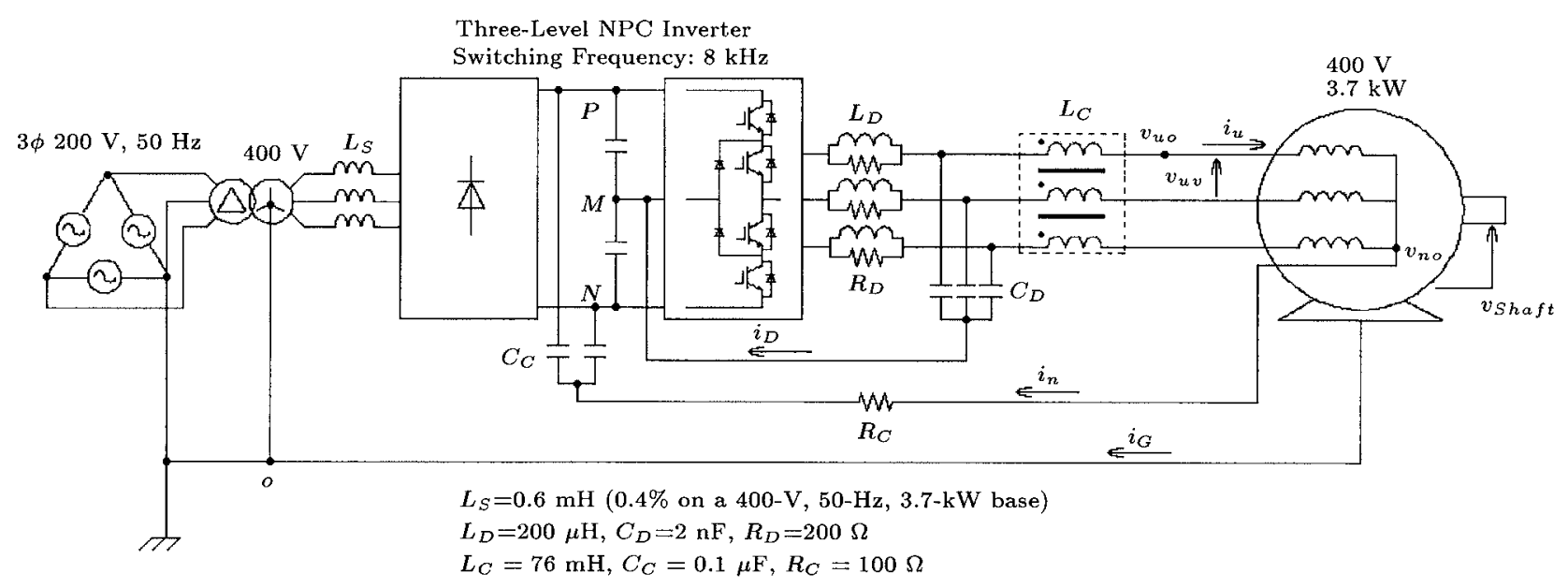

図 1 モータ中性線を利用したパッシブ EMI フィルタと実験システム構成

Fig. 1. The proposed passive EMI filter with access to the motor neutral line, and its experimental system configuration.

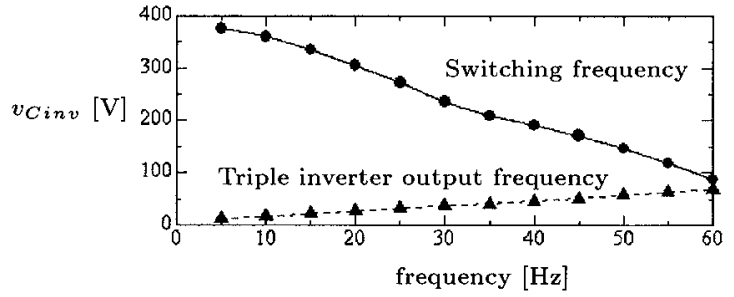

図 2 汎用 400-V NPC インバータのコモンモー ド電圧に含まれるスイッチング周波数成分

$(8 \mathrm{kHz})$ と出力周波数の 3 倍調波成分の実測值 (ピーク值)

Fig. 2. Measured common-mode peak voltages of the general-purpose 400-V NPC inverter for the switching frequency $(8 \mathrm{kHz})$ and the triple inverter output frequency.

\section{2. 実験システム}

〈2・1〉 システム構成＼cjkstart本論文で使用した実験システム を図 1 に示す。電源は接地系三相電源にインバータを直結 し, インバータには 3 レベル NPC (Neutral-Point-Clamped) インバータ (7), モータは三相誘導電動機 $(400 \mathrm{~V}, 3.7 \mathrm{~kW}$, 4 極）を用いた。パッシブ EMI フィルタは $d v / d t$ 抑制回路 とコモンモードフィルタで構成されている。 $d v / d t$ 抑制回 路は $L_{D}$ と $R_{D}$ の並列と $C_{D}$ で構成され, 相電圧, 線間電圧 の立上がり・立下り時に一次のローパスフィルタとして作 用することから，立上がり・立下り時の $d v / d t$ を抑制するこ とができる。コモンモードフィルタはコモンモードチョー ク $L_{C}$ と, モータ中性点とインバータ直流バスの正, 負側 の間の抵抗 $R_{C}$ とコンデンサ $C_{C}$ で構成されている。コモ ンモードチョーク $L_{C}$ は 1 つのコアに巻数, 極性が等しく なるようにエナメル線を巻いたものであり，コモンモード に対してのみ大きなインダクタンスを持つ。コモンモード フィルタは，モータ中性線をインバータ直流バスに接続す
ることにより，モータ浮遊容量に対し低インピーダンスの ループを構成できる。さらにインバータが発生するコモン モード電圧はほぼ全てコモンモードチョーク $L_{C}$ に印加さ れることから，モー夕端子においてコモンモード電圧を大 幅に抑制することができる。なお, ベアリング電流と接地 線へ流出する漏れ電流の抑制効果を評価するため, 本論文 ではインバータの放熱フィンは非接地とした。

〈2・2〉 NPC インバータの特性及びモータの構造＼cjkstart実 験に用いたNPC インバータの出力相電圧にはインバータ出 力周波数の 3 倍調波成分が含まれる。図 2 にインバータが 発生するコモンモード電圧 $v_{C i n v}$ のスイッチング周波数成分 $(8 \mathrm{kHz})$ 及び 3 倍調波成分 (最大 $180 \mathrm{~Hz}$ ) を示す。図 2 か ら, スイッチング周波数成分はインバータ周波数の増加に 伴い減少し，3 倍調波成分は増加している。出力周波数が $10 \mathrm{~Hz}$ 付近におけるスイッチング周波数成分は $350 \mathrm{~V}$ 程度 であり, 最も厳しい運転条件であることから, 実験ではイン バー夕周波数を $10 \mathrm{~Hz}$ とした。また，コモンモードチョー ク $L_{C}$ を設計する際, コモンモード電圧が最大になる点で磁 束が飽和しないようにする必要がある。本論文では, 飽和 磁束密度が $1.1 \mathrm{~T}$ であるリングコアを 2 個用いて, 出力周 波数 $10 \mathrm{~Hz}$ 付近において発生する最大磁束密度が $0.8 \mathrm{~T}$ で あるコモンモードチョークを設計した。図 3 に実験に使用 したコモンモードチョーク及びノーマルモードチョークを 示す。

困 4 に実験に使用したモータの概略図を示す。伝動側と 反伝動側の両方の軸受外輪とブラケットとの間に絶縁物を 挿入し, ベアリング電流がブラケットに流出しないように している。さらに絶縁物を挟むようにして伝動側のベアリ ング電流 $i_{B}$ を測定するための電線を軸受から引き出してい る†。

†絶縁ゴムマットを敷いて誘導電動機を絶縁し，接地線へ流出する 漏れ電流 $i_{G}$ を直接測定した。 


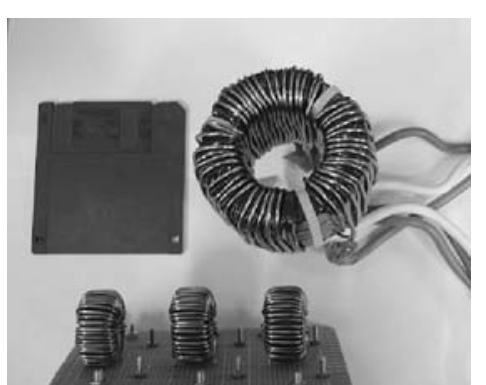

図 $376 \mathrm{mH}$ コモンモードチョーク（右上）と $200 \mu \mathrm{H}$ ノーマルモードチョーク（下）

Fig. 3. The 76-mH common-mode inductor (upper right) and the three $200-\mu \mathrm{H}$ differential-mode inductors (lower), compared with a 3.5 -inch floppy disk.

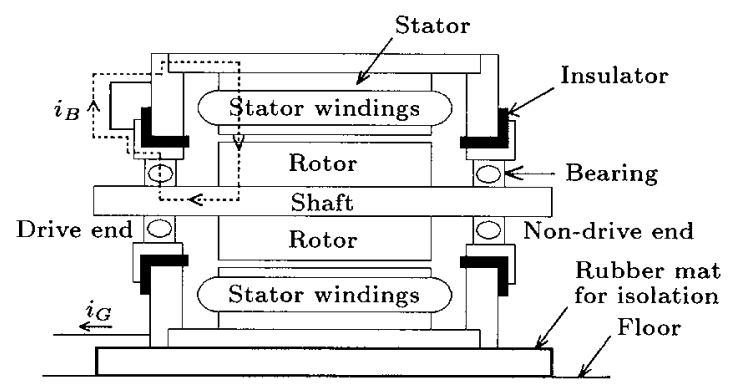

図 4 実験に使用したモー夕の概略図及び $i_{G}$ と $i_{B}$ の測定方法

Fig. 4. Sketch of the motor used in experiment, and measurement method of $i_{G}$ and $i_{B}$.

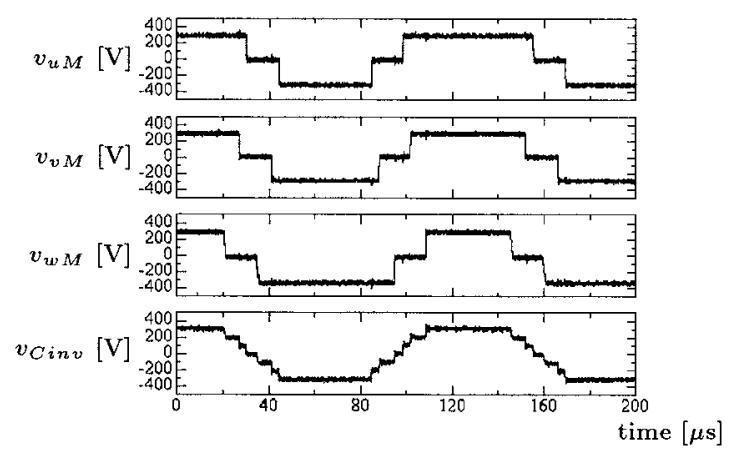

図 5 インバータ出力相電圧とコモンモード電圧 の実測波形（インバータ出力周波数 $10 \mathrm{~Hz}$ )

Fig. 5. Inverter output phase voltages and commonmode voltage at an inveter output frequency of $10 \mathrm{~Hz}$.

〈2·3〉 NPC インバータが発生するコモンモード電圧の 周波数依存性 図 5 にインバー夕出力周波数が $10 \mathrm{~Hz}$ の 場合のインバータ出力相電圧とコモンモード電圧の実測波 形を示す。これらの波形にダイオード整流器のコモンモー ド電圧を含まないようにするため, インバー夕直流バスの 中性点 $M$ を基準として測定を行った。本実験に使用した NPC インバータは, 出力周波数が低い場合にコモンモード 電圧 $v_{\text {Cinv }}$ が最大值となる $\mathrm{PPP}, \mathrm{NNN}^{\dagger}$ のスイッチングモー

\footnotetext{
${ }^{\dagger} \mathrm{NPC}$ インバー夕は $\pm E[\mathrm{~V}], 0 \mathrm{~V}$ の 3 レベルの相電圧を出力できる。 $\mathrm{P}$ は $+E[\mathrm{~V}], \mathrm{M}$ は $0 \mathrm{~V}, \mathrm{~N}$ は $-E[\mathrm{~V}]$ である。
}

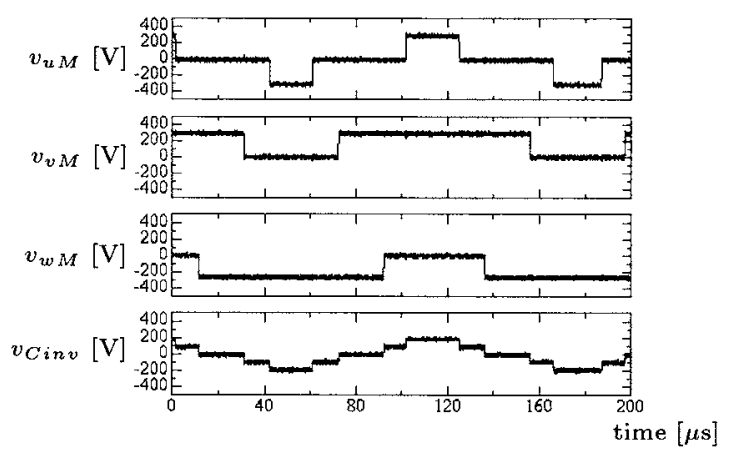

図 6 インバータ出力相電圧とコモンモード電圧 の実測波形（インバータ出力周波数 $40 \mathrm{~Hz}$ )

Fig. 6. Inverter output phase voltages and commonmode voltage at an inveter output frequency of $40 \mathrm{~Hz}$.

ドを出力をしている期間が長く, 図 5 からそのピーク值は $320 \mathrm{~V}$ である。

図 6 にインバー夕出力周波数 $40 \mathrm{~Hz}$ の運転時の各相電圧 及びコモンモード電圧の実測波形を示す。図 6 から, 各相 電圧のスイッチングパターンは PNM, PPN, PMM などの コモンモード電圧が小さくなるスイッチングパターンが多 い。この理由は, インバータ出力周波数が増加すると線間 電圧も増加するため, 各相で異なるスイッチングを行うか らである。図 6 からコモンモード電圧のピーク值は $200 \mathrm{~V}$ である。

\section{3. 出力周波数 $10 \mathrm{~Hz}$ での実験結果}

以下に，実測波形を示す。図 7〜図 11 において，(a) は スイッチング周波数基準時間軸，(b) は拡大波形，(c) は相 電圧, 線間電圧の拡大波形である。インバータは $V / f$ 一定 制御であり，出力周波数は $10 \mathrm{~Hz}$ ，モー夕は無負荷で運転 を行った。軸電圧 $v_{\text {Shaft }}$ はモータフレームを基準として測 定を行った。

〈3・1〉インバータとモータを直結した場合図7に インバータとモータを直結した場合の実測波形を示す†。イ ンバータが発生する $v_{\text {Cinv }}$ はモー夕に印加されることから, 軸受油膜に絶縁破壊電圧を超える電圧が印加され, 軸電圧 $v_{\text {Shaft }}$ は急激に $0 \mathrm{~V}$ となっている箇所がある。 $v_{\text {Shaft }}$ の波形 から油膜の絶縁破壊電圧は $10 １ 5 \mathrm{~V}$ であることがわかる。

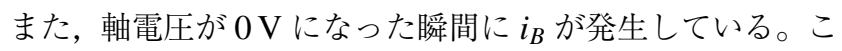
れは, 後述の図 12 の $C_{R F}$ に蓄積された電荷が放電したため であり，そのピーク值は $1 \mathrm{~A}$ 程度である。漏れ電流 $i_{G}$ は, $C_{S F}$ を通って流れるためコモンモード電圧の微分波形とな り, そのピーク值は $0.5 \mathrm{~A}$ 程度である。図 7(b) から， $i_{B}$ と $i_{G}$ は無関係であることがわかる。このことは, ベアリング 電流は接地線には流れず，モータ内部を循環することを意 味している。

相電圧 $v_{u o}$, 線間電圧 $v_{u v}$ の $d v / d t$ は最大で $3,700 \mathrm{~V} / \mu \mathrm{s}$ に

†図 7(a)の $v_{C m o t}$ は図 5 の $v_{C i n v}$ と一致する。図7(a)の $v_{C m o t}$ は $o$ 点 を基準とし, 図 5 の $v_{C i n v}$ は $M$ 点を基準として測定した。 


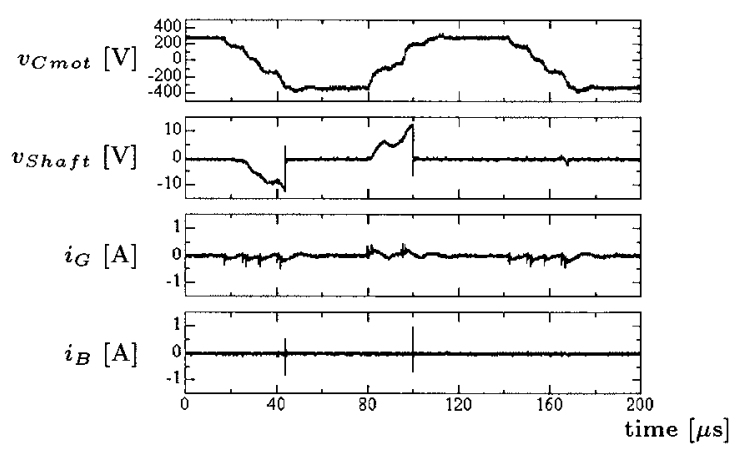

(a) Switching frequency-based time scale

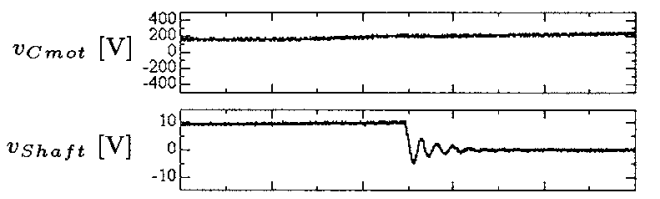

$i_{G}[\mathrm{~A}]$

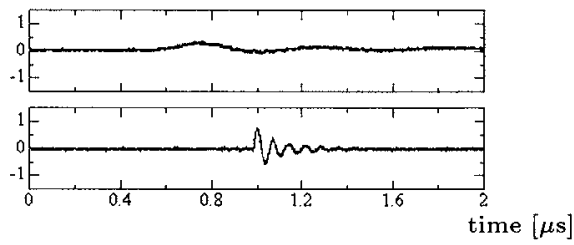

(b) Time-expanded waveforms of (a)

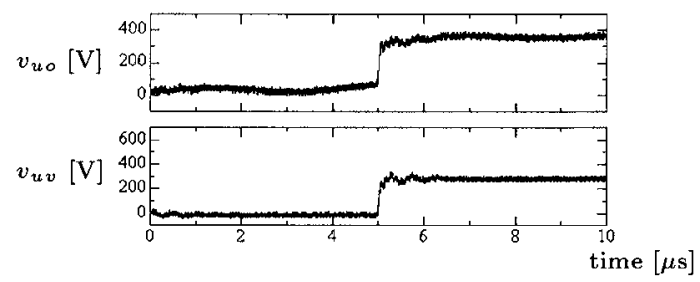

(c) Time-expanded waveforms of the phase-to-ground and line-to-line voltages

図 7 インバータとモータを直結した場合の 実測波形

Fig. 7. Experimental waveforms when no filter is connected.

達し, 巻線の絶縁劣化やノイズの原因となる。

$\langle\mathbf{3 \cdot 2 \rangle} \boldsymbol{d v} / \boldsymbol{d} \boldsymbol{t}$ 抑制回路のみを接続した場合＼cjkstart図 8 に $d v / d t$ 抑制回路のみを接続した場合の実測波形を示す。 $d v / d t$ 抑制回路を接続することによって相電圧，線間電圧の $d v / d t$ が $250 \mathrm{~V} / \mu \mathrm{s}$ まで抑制されている。よって巻線の絶縁劣化や ノイズの発生を抑制できると考えられる。しかし，モータ 端子の $v_{C m o t}$ は $d v / d t$ 抑制回路だけでは抑制することができ ない。その結果, $v_{\text {Shaft }}$ は図 7 と同様に $0 \mathrm{~V}$ となる箇所があ り，その瞬間に $i_{B}$ が発生している。つまり， $d v / d t$ 抑制回 路のみでは油膜の絶縁破壊に起因するベアリング電流抑制 できない。図 8 の $i_{G}$ は図 7 と同様な波形であるが，図 7(a) の $i_{G}$ に存在するサージ状の電流は発生していない。これは $d v / d t$ 抑制回路によって相電圧, 線間電圧の $d v / d t$ を大幅に 抑制した結果であると考えられる。

〈3·3〉 コモンモードチョーク $\boldsymbol{L}_{\boldsymbol{C}}$ のみを接続した場合

図 9 にコモンモードチョーク $L_{C}$ のみを接続した場合の 実測波形を示す。図 1 のモータ中性線は開放 $\left(i_{n}=0\right)$ し

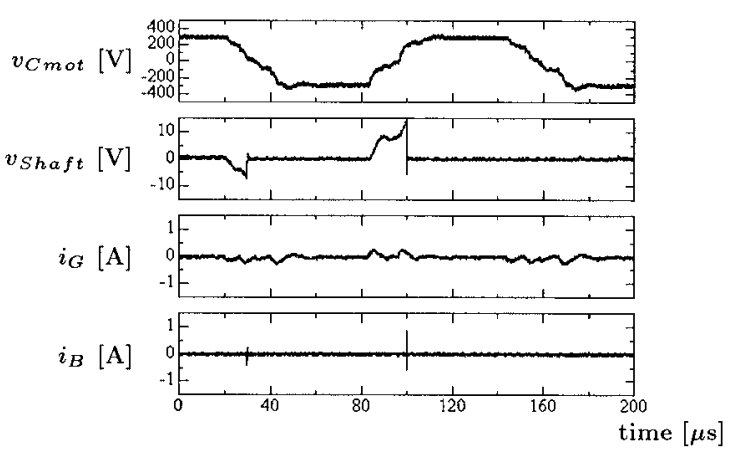

(a) Switching frequency-based time scale

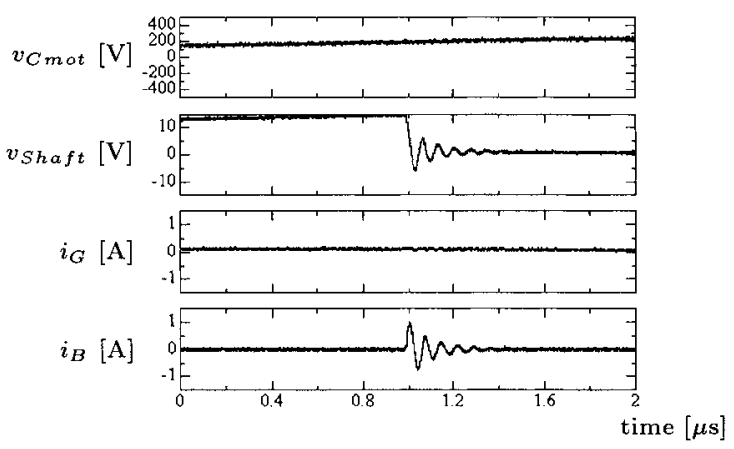

(b) Time-expanded waveforms of (a)

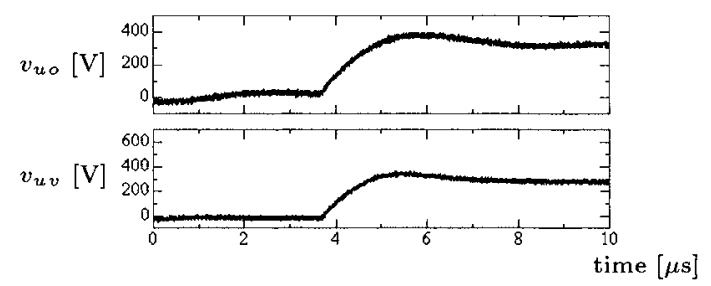

(c) Time-expanded waveforms of the phase-to-ground and line-to-line voltages

図 $8 d v / d t$ 抑制回路のみを接続した場合の 実測波形

Fig. 8. Experimental waveforms when only the $d v / d t$ reduction circuit is connected under $i_{n}=0$.

ている。 $L_{C}$ を接続しても $v_{S h a f t}$ には $0 \mathrm{~V}$ となる箇所があ り，その瞬間に $i_{B}$ が発生している。 $i_{B}$ のピーク值は $0.7 \mathrm{~A}$ であり, $L_{C}$ のみでも油膜の絶縁破壊に起因するべアリング 電流（放電電流）を完全には抑制できない。しかし， $i_{G}$ の ピーク值は $0.2 \mathrm{~A}$ であり, 図 7 よりも抑制されている。

相電圧 $v_{u o}$, 線間電圧 $v_{u v}$ の時間軸拡大波形には, $0.8 \mathrm{MHz}$ の振動が現れている。これは, コモンモードチョークの漏 れ磁束とモータの浮遊容量による共振現象である。

〈3・4〉コモンモードフィルタのみを接続した場合

図 10 にコモンモードフィルタのみを接続した場合の実測 波形を示す。コモンモードフィルタを接続したことによっ て，モー夕端子において $v_{C m o t}$ が大幅に抑制されることか ら, $v_{\text {S haft }}$ は軸受油膜の絶縁破壊電圧を超えることはなく, そのピーク值は $1 \mathrm{~V}$ 程度となっている。その結果, 油膜の 絶縁は確保され, コンデンサ $C_{R F}$ の放電に伴う $i_{B}$ は零と なる。図 10 のピーク值が $50 \mathrm{~mA}$ 程度のベアリング電流は, モータ端子のコモンモード電圧によって軸受油膜の浮遊容 


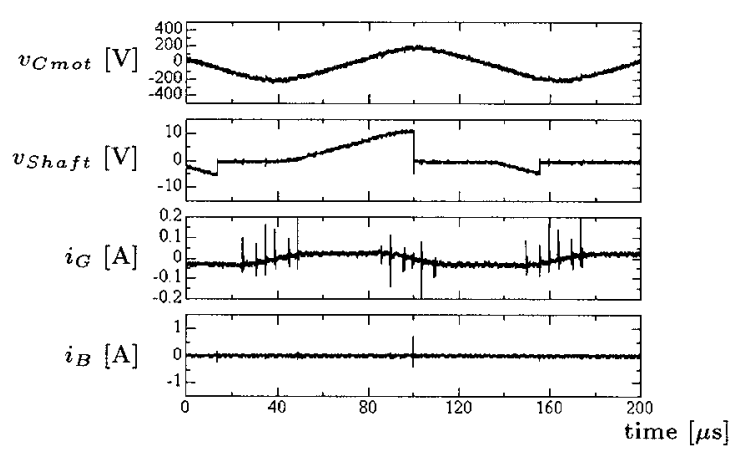

(a) Switching frequency-based time scale

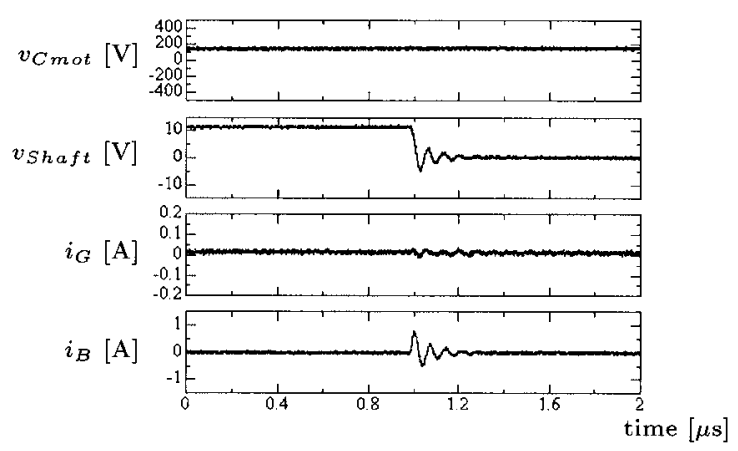

(b) Time-expanded waveforms of (a)

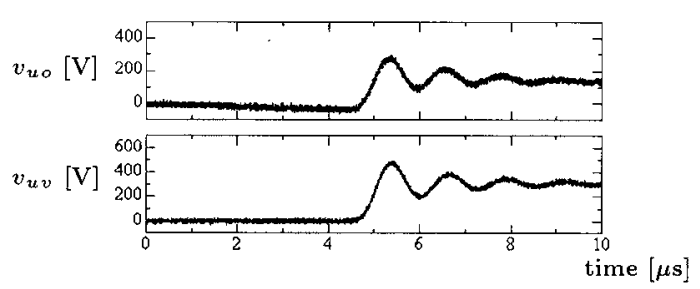

(c) Time-expanded waveforms of the phase-to-ground and line-to-line voltages

図 9 コモンモードチョークのみを接続した場合 の実測波形 (中性線開放)

Fig. 9. Experimental waveforms when only the commonmode inductor is connected under $i_{n}=0$.

表 1 実験条件の違いによる漏れ電流, ベアリン グ電流および $d v / d t$ の抑制効果

Table 1. Experimental conditions and their ground current, bearig current and $d v / d t$.

\begin{tabular}{|c|c|c|c|c|}
\hline & \multicolumn{2}{|c|}{$i_{G}[\mathrm{~mA}]$} & $i_{B}[\mathrm{~mA}]$ & $v_{u o}$ \\
\hline $\begin{array}{c}\text { Experimental } \\
\text { waveforms }\end{array}$ & $\begin{array}{c}\text { peak } \\
\text { current }\end{array}$ & $\begin{array}{c}\mathrm{rms} \\
\text { current }\end{array}$ & $\begin{array}{c}\text { peak } \\
\text { current }\end{array}$ & $\begin{array}{c}d v / d t \\
{[\mathrm{~V} / \mu \mathrm{s}]}\end{array}$ \\
\hline Fig.7 & 470 & 79 & 960 & 3,700 \\
\hline Fig.8 & 260 & 83 & 890 & 250 \\
\hline Fig.9 & 198 & 26 & 700 & 670 \\
\hline Fig.10 & 176 & 10 & 48 & 800 \\
\hline Fig.11 & 76 & 8 & 28 & 270 \\
\hline
\end{tabular}

量 $C_{B}$ を通って発生している変位電流であり，絶縁破壊に 起因する放電電流ではない。また，コモンモード電圧を抑 制した結果， $i_{G}$ のピーク值は $0.2 \mathrm{~A}$ ，実効值は $0.01 \mathrm{~A}$ に抑 制できている。

$\langle\mathbf{3 \cdot 5 \rangle} d v / d t$ 抑制回路とコモンモードフィルタを接続し た場合 図 11 に $d v / d t$ 抑制回路とコモンモードフィルタ

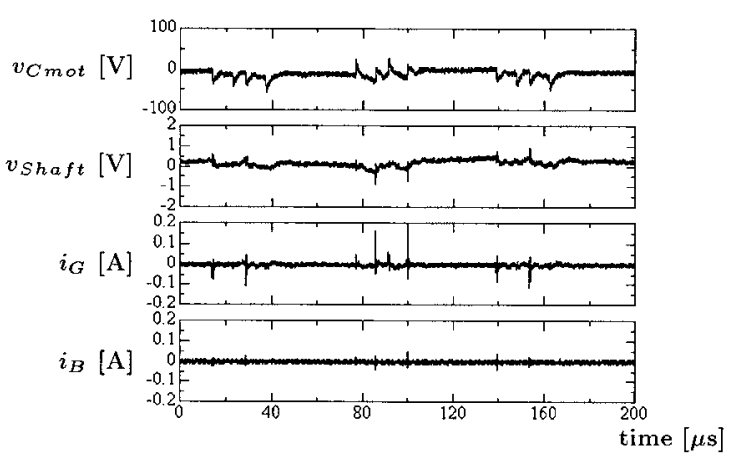

(a) Switching frequency-based time scale

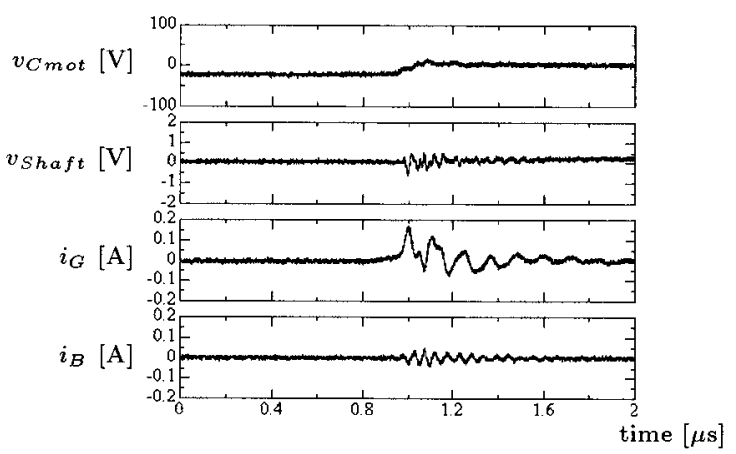

(b) Time-expanded waveforms of (a)

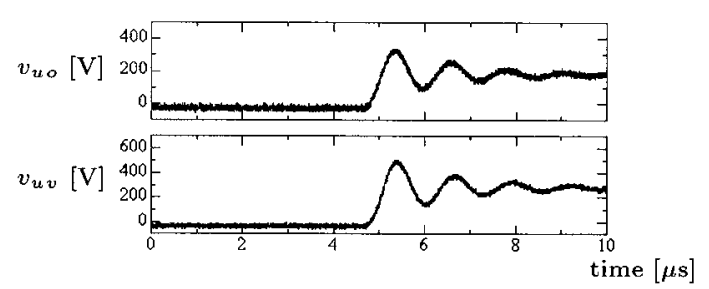

(c) Time-expanded waveforms of the phase-to-ground and line-to-line voltages

図 10 コモンモードフィルタのみを接続した場 合の実測波形

Fig. 10. Experimental waveforms when only the commonmode filter is connected.

を接続した場合の実測波形を示す。 $d v / d t$ 抑制回路を接続 したことによって相電圧, 線間電圧の $d v / d t$ が $270 \mathrm{~V} / \mu \mathrm{s}$ ま で抑制されている。このことから巻線の絶縁劣化やノイズ の発生を抑制できると考えられる。 $i_{G}$ と $i_{B}$ は図 10 と比較 してピーク值が減少している。モータ中性線と $d v / d t$ 抑制 回路を流れる電流から実効值を求め, 抵抗 $R_{D}, R_{C}$ の損失 を計算した。その結果， $R_{D}$ の損失は $6.7 \mathrm{~W}$ (三相分)， $R_{C}$ は $0.037 \mathrm{~W}$ となり，無視できる。

表 1 に漏れ電流のピーク值と実効值, ベアリング電流の ピーク值, 相電圧の $d v / d t$ の実測值を示す。この結果から, モータ中性線を利用したパッシブ EMI フィルタを設置する ことによって, ベアリング電流のピーク值を大幅に抑制で きる。また図 10 と図 11 の $i_{B}$ は軸受油膜の絶縁破壞に起 因するベアリング電流（放電電流）ではなく, 浮遊容量 $C_{B}$ を通るベアリング電流 (変位電流) であることから, $d v / d t$ を抑制することによって $20 \mathrm{~mA}$ 減少している。 


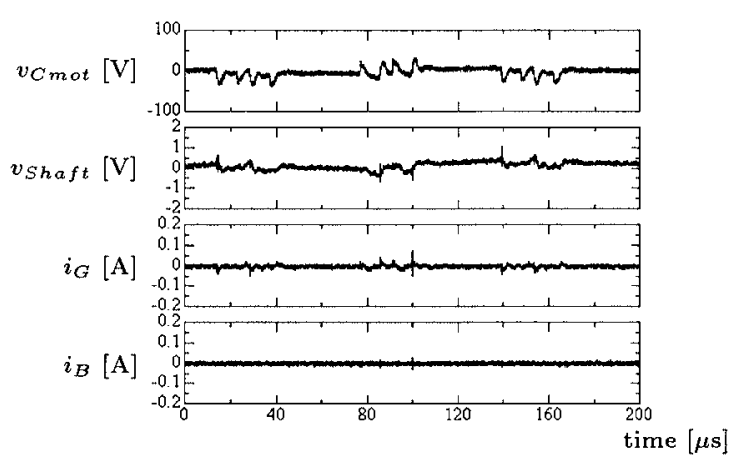

(a) Switching frequency-based time scale

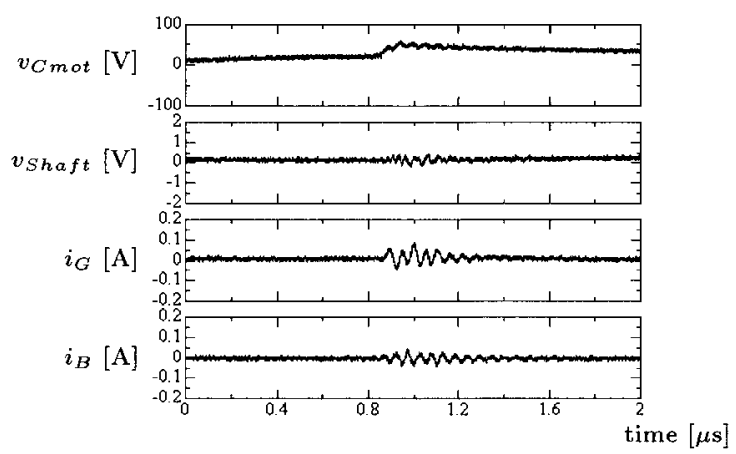

(b) Time-expanded waveforms of (a)

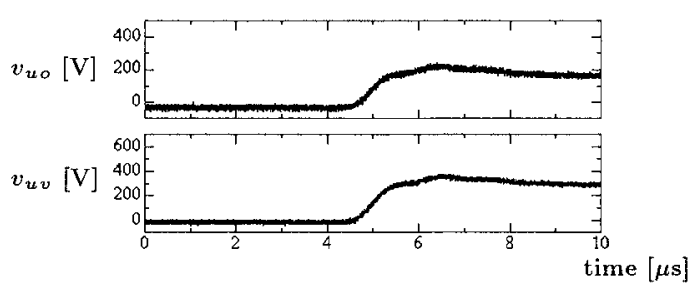

(c) Time-expanded waveforms of the phase-to-ground and line-to-line voltages

図 $11 d v / d t$ 抑制回路とコモンモードフィルタを 接続した場合の実測波形

Fig. 11. Experimental waveforms when the $d v / d t$ reduction circuit and the common-mode filter are connected.

\section{4. モータのコモンモードに対する等価回路}

〈4・1〉 ベアリング電流の経路インバータが発生す るコモンモード電圧 $v_{C i n v}$ は, 漏れ電流 $i_{G}$ とベアリング電 流 $i_{B}$ を誘発する。以下にその発生原理を説明する。図 12 にモータ内部のコモンモードに対する等価回路を示す ${ }^{(3)}$ 。 $C_{S F}$ は固定子巻線とフレーム間の浮遊容量, $C_{S R}$ は固定子 巻線と回転子間の浮遊容量, $C_{R F}$ は回転子とフレーム間の 浮遊容量, $C_{B}$ は油膜間の浮遊容量, $C_{I n s}$ はモータのブラ ケット間に挿入した絶縁物の容量，等価スイッチ $S W$ は軸 電圧 $v_{\text {Shaft }}$ が絶縁破壊電圧以下ではオフであり，軸受は $C_{B}$ として作用するが，絶縁破壊電圧を超えるとオン状態とな り，軸受は短絡として作用する。各浮遊容量の值はモー夕 容量や極数によって異なる。図 12 からコモンモード電圧 $v_{C m o t}$ を電圧源とする電流経路は 3 種類存在する。

- $C_{S F}$ を経由：固定子巻線 $\rightarrow$ フレーム $\rightarrow$ 接地線

- $C_{S R}$ と $C_{R F}$ を経由：固定子巻線 $\rightarrow$ 回転子 $\rightarrow$ フレーム

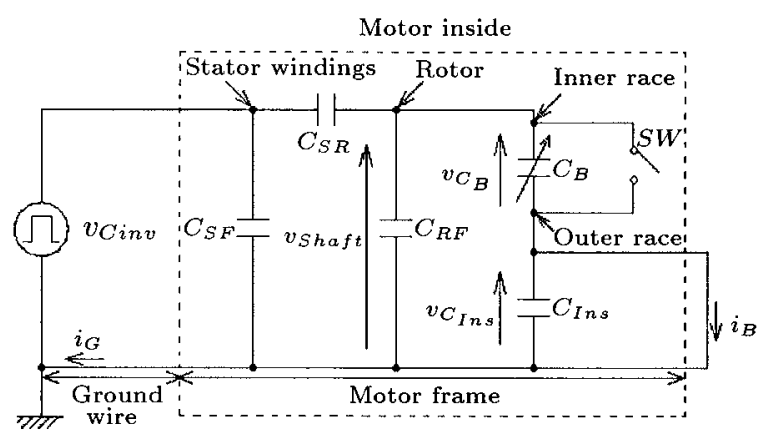

$C_{S F}=3,600 \mathrm{pF}, C_{S R}=64 \mathrm{pF}, C_{R F}=1,200 \mathrm{pF}$ $C_{B}=210 \sim 470 \mathrm{pF}, C_{I n s}=93 \mathrm{pF}$

図 12 モータのコモンモード等価回路

Fig. 12. Equivalent circuit to the motor for common mode.

$\rightarrow$ 接地線

- $C_{S R}$ と $C_{B}$ を経由 : 固定子巻線 $\rightarrow$ 回転子 $\rightarrow$ 軸 $\rightarrow$ 軸 受 $\rightarrow$ ブラケット $\rightarrow$ フレーム $\rightarrow$ 接地線

これらの接地線を流れる電流が漏れ電流 $i_{G}$ となる。油膜の 絶縁破壊が発生した場合は， $C_{R F}$ を電圧源として

- $C_{R F}$ とスイッチ $S W$ のループ: 回転子 $\rightarrow$ 軸 $\rightarrow$ 軸受 $\rightarrow$ ブラケット $\rightarrow$ 回転子

という電流経路が構成される。この電流がベアリング電流 $i_{B}$ であり，モー夕内部を循環し，接地線には流出しない。

第 1 章で紹介したベアリング電流抑制法と本論文の方法 を図 12 を用いて説明する。(1)の静電シールドを挿入した 誘導電動機は, 固定子巻線と回転子間の浮遊容量 $C_{S R}$ を非 常に小さくすることによって，回転子側を電気的に絶縁す る方法である。(2) は接地ブラシを用いて $C_{R F}$ の両端を短 絡することにより， $C_{R F}$ の蓄積電荷を零にする方法である。 (3) は絶縁破壊が発生した場合の $i_{B}$ の電流ループの一部に 絶縁物を挿入し，電流ループを開放にする方法である。

これらに対して，本論文で採用している方法はべアリン グ電流の発生原因であるコモンモード電圧 $v_{C m o t}$ を抑制し, ベアリング電流を抑制している点が従来の方法と大きく異 なる。

〈4・2〉浮遊容量の測定 図 12 の浮遊容量に関するす ベての実験は, 軸受の外輪（Outer race）とモータフレーム との間のベアリング電流測定用電線を開放した。

まず，モー夕を停止した状態で固定子巻線一フレーム間， 軸一フレーム間のインピーダンス特性やを測定する。モータ 停止状態では図 12 のスイッチ $S W$ はオンであり, $C_{B}$ は無 視できる。一方，ベアリング電流測定用電線を開放してい るので, 絶縁物は $C_{I n s}$ として作用する。図 13 と図 14 にイ ンピーダンス特性を示す。スイッチング周波数付近ではコ ンデンサと等価であり, $C_{1}=3,600 \mathrm{pF}, C_{2}=1,300 \mathrm{pF}$ と なる。これらは, 固定子巻線一フレーム間の

\footnotetext{
†測定には，バイポーラ電源 HSA4101（NF 回路設計ブロック）と ファンクションジェネレータを用い，電圧，電流の振幅，位相差を測 定した。
} 


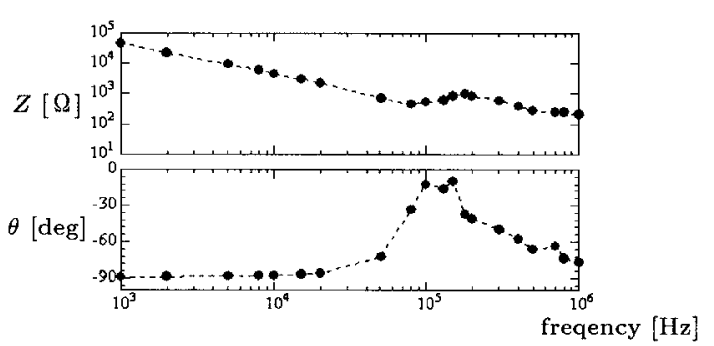

図 13 モータのコモンモードに対するインピー ダンス特性の実測值（固定子巻線一フレーム）

Fig. 13. Measured common-mode impedance characteristics of the tested motor between the three power lines and the motor frame.

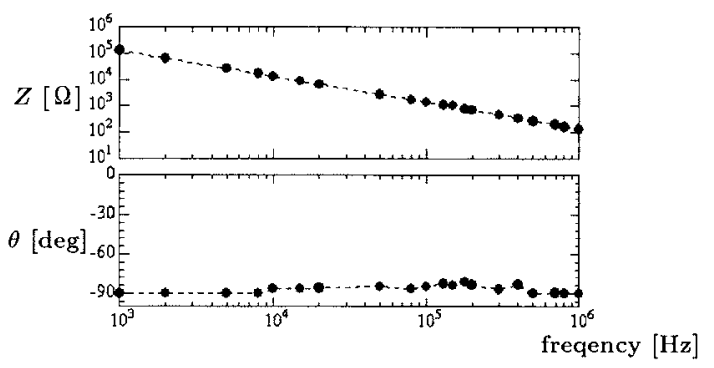

図 14 モータのコモンモードに対するインピー ダンス特性の実測值（軸一フレーム）

Fig. 14. Measured common-mode impedance characteristics of the tested motor between the three power lines and the motor frame.

$$
C_{1}=C_{S F} / /\left(C_{S R}+\left(C_{R F} / / C_{I n s}\right)\right)
$$

軸一フレーム間の

$$
C_{2}=\left(C_{S F}+C_{S R}\right) / /\left(C_{R F} / / C_{I n s}\right)
$$

を測定したことになる。ここで固定子巻線とフレーム間の 浮遊容量 $C_{S F}$ は数 $\mathrm{nF}$ であるのに対し, 固定子巻線と回転 子間の浮遊容量 $C_{S R}$ は数 $10 \mathrm{pF}$ と非常に小さいので, $C_{S R}$ は開放として考える。よって，固定子巻線一フレーム間は $C_{1} \simeq C_{S F}$ で近似でき, $C_{S F}=3,600 \mathrm{pF}$ を得る。しかし， 軸一フレーム間は

$$
C_{2} \simeq C_{R F} / / C_{I n s}
$$

となる。

次に $C_{B}$ について検討する。 $C_{B}$ はスライドレギュレータ を用いて回転子を回転させ，軸受の内輪（Inner race）と外 輪（Outer race）との間の浮遊容量 $C_{3}$ を LCR メータを用 いて測定した。これは

$$
C_{3} \simeq C_{B} / /\left(C_{I n s}+C_{R F}\right)
$$

を測定したことになる。モータが回転している状態 $(300 \mathrm{rpm}$ 以上）では軸受は $C_{B}$ として作用することから， $v_{\text {Shaft }}$ は $C_{B}$ と $C_{I n s}$ で分圧される。図 15 に $d v / d t$ 抑制回路とコモ ンモードフィルタを接続した場合の軸電圧 $v_{S \text { haft }}$ と絶縁物 電圧 $v_{C I n s}$ と $C_{B}$ の電圧 $v_{C_{B}}$ の実測波形を示す。図 15 から

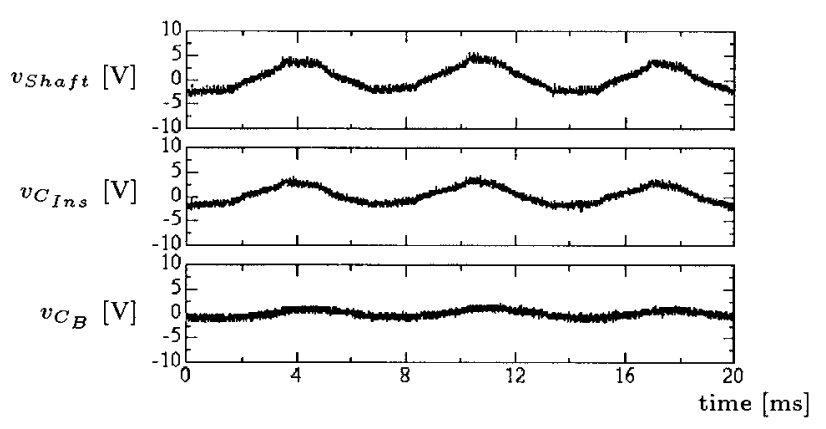

困 $15 v_{S h a f t}, v_{C_{B}}, v_{C_{\text {Ins }}}$ の実測波形(インバータ 出力周波数 $10 \mathrm{~Hz}$ )

Fig. 15. Experimental waveforms of $v_{S h a f t}, v_{C_{B}}$ and $v_{C_{I n s}}$ when the inverter output frequency is $10 \mathrm{~Hz}$.

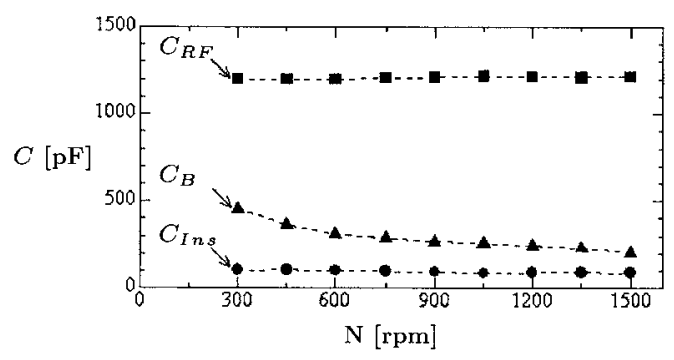

図 $16 C_{B}, C_{I n s}, C_{R F}$ の回転数依存性の実測結果

Fig. 16. Measured results of dependency of $C_{B}, C_{\text {Ins }}$ and $C_{R F}$ on motor rotating speed.

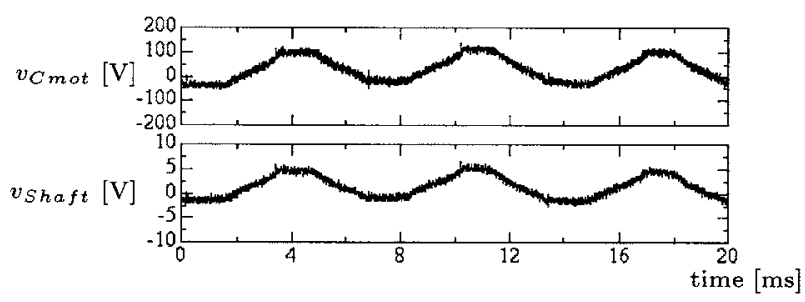

図 17 図 1 のモー夕端子のコモンモード電圧と 軸電圧の実測波形（インバータ出力周波数 $10 \mathrm{~Hz}$ )

Fig. 17. Experimental waveforms of the motor commonmode voltage, and the shaft voltage in Fig. 1 when the inverter output frequency is $10 \mathrm{~Hz}$.

$v_{C_{I n s}} / v_{C_{B}} \simeq 4.4$ となり,

$C_{B} \simeq 4.4 C_{\text {Ins }}$

となる。よって式 (3), (4), (5) から $C_{B}, C_{I n s}, C_{R F}$ を算出 することができる。図 16 に算出した $C_{B}, C_{I n s}, C_{R F}$ の回 転数依存性を示す であり $C_{I n s}=93 \mathrm{pF}, C_{R F}=1,200 \mathrm{pF}$ となる。しかし $C_{B}$ の值は回転数の増加と共に減少していることがわかる。こ の理由は回転数によって油膜の状態が変化するためである と考えられる。

$C_{S R}$ については, モータ端子のコモンモード電圧 $v_{C m o t}$

†モー夕停止時や低速時（250 rpm 以下）では，ボールが内輪と外輪 に接触しているため軸受は短絡状態となり, 等価スイッチ $S W$ はオン 状態であると考えられる。このため $250 \mathrm{rpm}$ 以下では $C_{B}$ を測定でき ない。 
と軸電圧 $v_{S h a f t}$ の分圧比から求めることができる。この分 圧比は $C_{S R}$ と $C_{R F} / /\left(C_{B}+C_{I n s}\right)$ の值で決まる。図 17 に $d v / d t$ 抑制回路とコモンモードフィル夕を接続した場合の モー夕端子のコモンモード電圧 $v_{C m o t}$ と軸電圧 $v_{\text {Shaft }}$ の波 形を示す。図 17 から電圧比は $v_{C m o t} / v_{\text {Shaft }}=21$ となり, こ の比と $C_{B}, C_{I n s}, C_{R F}$ の值から $C_{S R}=64 \mathrm{pF}$ となる。

\section{5. 出力周波数 $40 \mathrm{~Hz}$ で運転した場合}

軸電圧 $v_{S h a f t}$ はインバータのコモンモード電圧 $v_{C i n v}$ と $C_{R F} / / C_{B}$ の值で決まる。

$C_{R F}$ の值が $1,200 \mathrm{pF}$ であることから，回転数が $1,500 \mathrm{rpm}$ から $300 \mathrm{rpm}$ に減少すると $C_{B}$ は $210 \mathrm{pF}$ から $470 \mathrm{pF}$ に増加 するが, $C_{R F} / / C_{B}$ の值は $1,410 \sim 1,670 \mathrm{pF}$ である。よっ て $C_{B}$ の回転数依存性は実用上は無視することができ，軸 受油膜のインピーダンスはほぼ一定となる。一方, 本研究 で用いた NPC インバータが発生するコモンモード電圧の スイッチング周波数成分 $v_{\text {Cinv }}$ は, 出力周波数を $10 \mathrm{~Hz}$ から $60 \mathrm{~Hz}$ に増加させると, 図 2 に示すように $370 \mathrm{~V}$ から $90 \mathrm{~V}$ に減少する。つまり軸受油膜のインピーダンスの変化より も出力周波数の変化に伴うコモンモード電圧の変化が支配 的となり，インバータ周波数が高くなるにつれて軸受油膜 の絶縁破壊は発生しにくくなる。そこで, ベアリング電流 測定用電線を接続し，インバータとモー夕を直結して実験 を行った。図 18 は出力周波数が $40 \mathrm{~Hz}$ の場合の実測波形 である。コモンモード電圧 $v_{C m o t}$ が減少したことにより，(a)

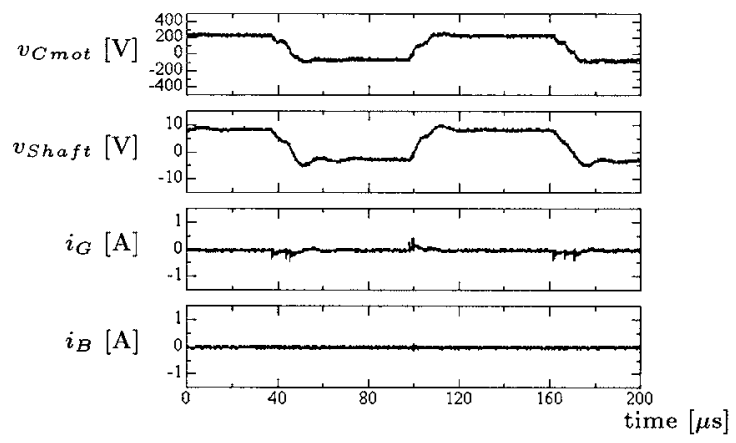

(a) Swithcing frequency-based time scale

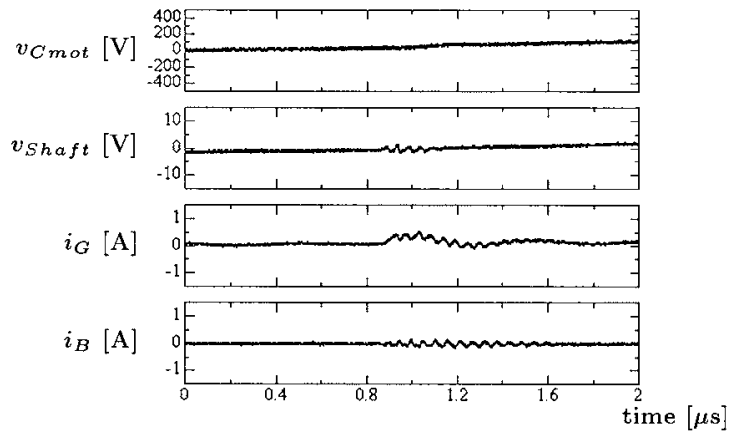

(b) Time-expanded waveforms of (a)

図 18 インバータとモータを直結した場合の実 測波形（出力周波数 $40 \mathrm{~Hz}$ )

Fig. 18. Experimental waveforms when no filter is connected, and the inverter output frequency is $40 \mathrm{~Hz}$.
の $v_{\text {Shaft }}$ の波形から軸受油膜の絶縁は確保されていること がわかる。その結果，(b)の $i_{B}$ のピーク值は $170 \mathrm{~mA}$ であっ た。これは $v_{C m o t}$ の $d v / d t$ に起因するべアリング電流（変位 電流）であり，軸受油膜の絶縁破壊に起因するベアリング 電流（放電電流）ではない。

\section{6. 結 論}

インバータとモータを直結した場合に流れるベアリング 電流（放電電流）はモータ内部を循環し, 接地線には流出 しない。一方，インバータとモータ間にパッシブ EMI フィ ル夕を接続すると, モー夕端子のコモンモード電圧を大幅 に抑制できるので，モータ内部を循環するべアリング電流 は流れず, しかもモータから接地線へ流出する漏れ電流も 抑制できる。なお, 本論文では三相誘導電動機を対象とし ているが，三相永久磁石電動機においても適用できる。 (平成 16 年 7 月 23 日受付, 平成 17 年 4 月 18 日再受付)

\section{文献}

（1） 奥山吉彦・藤井秀樹：「インバー夕駆動誘導電動機の軸電圧」, 富士 技報, Vol.72, No.2, pp.144-149 (1999)

(2) M. Nakamura and A. Imayanagita: "Bearing Corrosion of Induction Motors", Toyo Denki Review, No.105, pp.23-32 (2000-3) (in Japanese) 中村雅憲·今柳田明夫：「誘導電動機の軸受電食」, 東洋電機技報, 第 105 号, pp.23-32 (2000)

(3) D. Busse, J. Erdman, R.J. Kerkman, D. Schlegel, and G. Skibinski: "Bearing Currents and Their Relationship to PWM Drives", IEEE Trans. Power Electron., Vol.12, No.2, pp.243-252 (1997)

(4) D. Macdonald and W. Gray: "PWM Drive Related Bearing Failures", IEEE Industry Applications Magazine, Vol.5, No.4, pp.41-47 (1999)

（5）「インバー夕駆動誘導電動機の技術的諸問題」, 電気学会技術報告（II 部), 第 287 号, pp.19-26 (1988-12)

(6) T. Doumoto and H. Akagi: "An Approach to Suppressing Both Shaft Voltage and Leakage Current in an AC Motor Driven by a Voltage-Source PWM Inverter- - A Passive EMI Filter Making Use of the Motor Neutral Line-—", IEEJ Trans. IA, Vol.123, No.9, pp.1057-1064 (2003-9) (in Japanese)

堂元貴史・赤木泰文：「電圧形 PWM インバータの駆動交流電動機 の軸電圧・漏れ電流の一抑制法—モータ中性線を利用したパッシブ EMI フィルター」, 電学論 D, 123, 9, pp.1057-1064 (2003-9)

(7) A. Nabae, I. Takahashi, and H. Akagi: "A New Neutral-Point-Clamped PWM Inverter”, IEEE Trans. IA., Vol.17, No.5, pp.518-523 (1981)

田村 俊 輔 (学生員) 1979 年 4 月 4 日生。 2002 年 3 月武

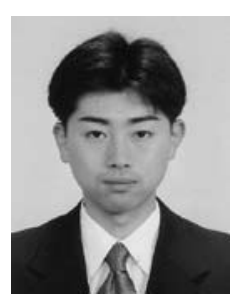
蔵工業大学工学部電気電子工学科卒業。2005 年 3 月東京工業大学大学院理工学研究科電気電子工 学専攻修士課程修了。同年 4 月東京電力に入社, 現在に至る。在学中はパッシブ EMI フィルタの 研究に従事。

赤 木 泰 文 (正員) 1951 年 8 月 19 日生。1979年 3 月東京工

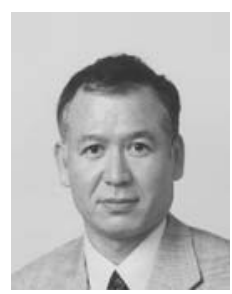
業大学大学院博士課程電気工学専攻修了, 工学博 士。長岡技術科学大学助手 · 助教授, 岡山大学教 授を経て, 2000 年 1 月東京工業大学教授。パワー エレクトロニクスの研究に従事。2001 年 IEEE William E. Newell Power Electronics Award。2004 年 IEEE IAS Outstanding Achievement Award。 